\title{
Are Farmers Trapped in Hold-Up Relationships with their Contractors in the Supply Chain? The Case of Dairy Farmers and Feed Suppliers
}

\begin{abstract}
Agricultural production is widely discussed in the context of imbalances in bargaining power in the food chain and farmers' difficult position relative to their contractors. The paper attempts to explain the nature and reasons of the bargaining power imbalances that may lead to hold-up relationships in the farming sector in the light of the Transaction Costs Theory (TCT). In order to provide a certain focus, the theoretical discussion is illustrated by an empirical example of backward vertical relations between farmers and input (feed) suppliers. The article investigates the reasons for long-term and stable relationships between farmers and feed suppliers and whether these may be partly explained by an imbalance in bargaining power, trapping farmers in the specific monopolistic (hold-up) relations with their contractors.

Overall, the picture that emerges from the analysis does not support the assumptions that farmers are experiencing a large imbalance in bargaining power with regard to their input contractors, and are trapped in a specific monopolistic (hold-up) relationship with them. Despite that there is no written contract between the farmers and their suppliers, relations are based on unwritten, privately enforced terms. The parties tend to respect the mutually agreed relationship rather than breaching it ex-post in order extract the holdup quasi-rents. In this case a binding written supply commitment may increase transaction costs, limit the freedom to change supplier and reduce the farmer's bargaining power over the feed producer by adding additional inter-dependency.
\end{abstract}

Keywords: bargaining power imbalance, hold-up problem, vertical integration, dairy farmers, feed suppliers, Transaction Costs Theory.

\section{Introduction}

Market imbalances in bargaining power between farmers relative to chain contractors was emphasised recently in the OECD (2018), and it is generally

Agata Malak-Rawlikowska, PhD, Faculty of Economic Sciences, Warsaw University of Life Sciences (SGGW), Nowoursynowska 166, 02-787 Warsaw, agata_malak_rawlikowska@sggw.pl. 
a widely discussed issue. This problem was also reflected in the Rural Development Programme (2014-2020), where one of its key priorities focuses, broadly speaking, on "improving food chain organisation". Masten (2000) stated that "the most explicit attribute distinguishing agricultural goods from other commodities is their perishability", which poses contractual hazards for which comparative contractual reasoning is needed (Williamson 2004). In reality not all agricultural products are perishable, but what might be added here as problematic is the agricultural sector specificity deriving from production in natural conditions, low mobility of assets, and long production cycles. One of the main weaknesses of the agricultural sector is its fragmentation. This causes a significant imbalance of powers in the food chain, as well as maladjustment between the dispersed production segment and usually concentrated downstream and upstream segments of the chain. The role of agriculture in generating externalities, both positive and negative, is also important. The specific characteristics of agriculture, as well as the resulting from them effects, are referred to by agricultural economists as an agrarian issue (e.g. Czyżewski and Kułyk 2013, 2015; Masten 2000; Rembisz and Stańko 2007; Swinnen 2007; Wilkin 2009). This issue on the one hand implies that agricultural producers are vulnerable to opportunistic contractors (e.g. processors), who, by imperfections (incompleteness, asymmetry of information) of the contractual arrangements, can gain a bargaining advantage, leading them to renegotiate the contracts. On the other hand, commercial food distribution channels cannot easily deal with individual, especially small farms due to high transaction costs of contracting for a small volume of product, potential problems with the required quality and intermittent supply from a single farm. This problem undoubtedly seems to be understood in Transaction Costs Theory (TCT) reasoning, and needs deeper attention.

As discussed by number of authors, bargaining power can be expressed by different measures (i.e. Milczarek-Andrzejewska 2014). Quantitative works most often refer to farm size (quantities produced), quality of produce, the distance between contractors, and farmers' outside options - for example, access to offfarm jobs (Fałkowski, Malak-Rawlikowska and Milczarek-Andrzejewska 2017). ${ }^{1}$ According to transaction costs and property rights approaches, exercising power in the supply chain depends on whether a given party can credibly threaten another with switching to an alternative contractor. In an extreme situation, a party has all the bargaining power if it can make a take-it-or-leave-it offer to the current business partner. Accordingly, the bargaining power of the farm increases via the substitutability of inputs it needs to purchase and the substitutability of contractors

1 For a discussion regarding this issue see Fałkowski, Malak-Rawlikowska and Milczarek-Andrzejewska (2017) or Milczarek-Andrzejewska (2014). 
that can potentially buy its output (Antras 2016; Fałkowski, Malak-Rawlikowska and Milczarek-Andrzejewska 2017). Thus the smaller the losses a farm would incur when it decides to contract inputs outside of the specific relationship, the stronger is its bargaining power in this relationship. It implies that the bargaining power is greater on the side of the partner who potentially has least to lose by breaching the contract. In the light of New Institutional Economics, specifically in the Transaction Cost Theory (TCT) of Coase (1937), developed further by Williamson (1989 and 1998), the imbalance in the bargaining power between the contractors could lead to a hold-up situation (i.e. monopolistic relationship with a contractor), when one of the transacting parties attempts to extract the appropriable quasi-rents accruing to the transaction-specific investment by ex-post renegotiating the contractual terms, that is holding-up the transaction (Klein, Crawford and Alchian 1978; Williamson 1998). The hold-up problem is thus "the general business problem in which each party to a contract worries about being forced to accept disadvantageous terms later, after it has sunk as investment, or worries that its investment may be devalued by others" (Milgrom and Roberts 1992).

An extensive literature has emerged to improve our understanding of vertical relations throughout the food chain (e.g. Chorób 2017; Dries et al. 2009 and 2014; Francesconi, Heerink and D'Haese, 2010; Gorton and White 2007; Jarzębowski 2013; Parzonko 2013; Pietrzak 2006 and 2019; Shuqin, Bluemling and Mol 2015; Strzębicki 2014; Swinnen 2007; Trebbin 2014; Vorley et al. 2007; Ward 2010). The restructuring of supply chains has been one of the most remarkable processes observed in the world's agri-food sector in recent years. The above-mentioned studies, however, have usually dealt with the issue of farmers' vertical relationships with downstream stages of the food chain. Most of the existing studies concentrate on either farmer-processor or farmer-retailer relationships. The studies covering farmers' backward vertical linkages towards input suppliers are very limited, with some notable exceptions such as Kuijpers and Swinnen (2016), Malak-Rawlikowska and Milczarek-Andrzejewska (2016) and Tiessen and Funk (1993). Moreover, only a few studies have directly concerned the problem of transaction costs and hold-up relationships, that may occur in the farming sector (e.g. Dresher 2000; Fernandez-Olmos, Rosell-Martınez and Espitia-Escuer 2009; Gow and Swinnen 1998 and 2002; Hess, Lind and Liang 2013; Holloway et al. 2000).

The main objective of the paper is therefore, in the light of TCT, to explain the nature of and reasons for the bargaining power imbalances that may lead to hold-up relationships in the farming sector. Despite the rich general-economic literature in the field of "hold-up problems", the studies related to agriculture are scarce, so the author attempts to fill this gap by discussing this problem in an agricultural sector context. In order to provide a certain focus of the paper, the 
theoretical discussion is illustrated by an empirical example (from authors' previous studies) of backward vertical relations between farmers and input (feed) suppliers, which is another of the paper's contributions to the limited literature in this regard. The article seeks to investigate the reasons for long-term and stable relationships between farmers and feed suppliers and whether these could be partly explained by an imbalance in bargaining power trapping farmers in the specific monopolistic (hold-up) relations with their contractors.

\section{Theoretical framework of hold-up relations - an agricultural sector perspective}

\subsection{Transaction costs, asset specificity and hold-ups}

In the light of Coase's (1937) and Williamsons' (1998) theory, vertical coordination in the supply chain is perceived as a key solution to reduce the negative effects of market imperfections and save in transaction costs. One of the sources of these costs and risks are market failures (Williamson 1998), in which Perry (2008) includes: imperfect competition, externalities and asymmetry of information. The key issue when it comes to transaction costs in Williamson's terms, (also emphasised by Perry), is the problem of asset specificity. In the absence of credible and enforceable contractual arrangements, there is an opportunity for one of the transacting parties to extract the quasi-rents accruing to the transaction-specific investment by ex-post renegotiation of the contractual terms, that is holding up the transaction (Klein, Crawford and Alchian 1978; Williamson 1998). The issue of the asset specificity is thus the key to understanding the hold-up mechanism.

As emphasised by Perry (2008), asset specificity means that an upstream or downstream partner has made specific investments dedicated only to this bilateral transaction. Thus the value of the transaction is greater than transactions with the other parties, and the relations between them tend to have a bilateral, even monopolistic character. Due to the risk of opportunistic ${ }^{2}$ behaviour by the contracting parties, this bilateral relationship my turn into a hold-up situation, where one of the parties attempts to extract "appropriable quasi-rents" (Klein, Crawford and Alchain (1978) after Perry (2008)), which result from a difference between the asset in this transaction and the next best use of it. However, in the case of a bilateral monopoly, specific investments by each contract partner may protect them from each other's opportunism (Dreascher 2000). Thus, generally speaking,

2 Williamson (1998, p. 47) defines opportunism as: "self-interest seeking guile. More generally refers to the incomplete or distorted disclosure of information, especially to calculated efforts to mislead, distort, obfuscate, or otherwise confuse". 


\section{the risk and range of a hold-up problem rises together with a degree of asset} specificity (Klein 1996) and the propensity to present opportunistic behaviour by contractors (as termed by Williamson 1998) or transactors' ignorance (as termed by Klein 1996, p. 445).

Williamson (1998) mentioned the following types of asset specificity that may occur in the transaction:

Site or location specificity: when certain assets are located in an area that makes it useful only to a small number of buyers or suppliers, e.g. farm location close to the processor or input supplier.

Physical-asset specificity: investment in specialist products or equipment that make them useful to only a small number of buyers, e.g. machinery dedicated to certain requirements of processors or suppliers (special storage facilities, labelling/ packing machinery, product sorting equipment etc.).

Human-asset specificity: any situation which increases specialist knowledge or human mobility which is specific to particular transaction, e.g. specific production knowledge or skills.

Dedicated assets: deals with the increase in the production scale/powers/ facilities dedicated to the certain buyer, e.g. contract farming in pig production.

Added later by Malone, Yates and Benjamin (1987), Temporal specificity: ${ }^{3}$ an asset is time-specific if its value is highly dependent on its reaching the user within a specified, relatively limited period of time, e.g. daily deliveries of milk to a dairy.

Location specificity is a very common transaction feature in agriculture, due to the limited mobility of farms and agricultural land and processing plants or other purchasers of farm products (Czyżewski 2009). Transportation costs are then the main determinant of the transaction. For example, farmers delivering to a dairy have a limited choice of alternative processors, who are able to collect milk from their farms. Nowadays, together with development of milk storage and transportation technologies, farmers have a much broader choice of purchasers (Roman 2017); however, the problem still exists. It creates an unequal bargaining relationship with the buyer, who could generate quasi-rents from this relationship by changing the transaction conditions or renegotiating the contract ex-post. Among others, Gow and Swinnen (1998) described this problem by the example of delayed payments for farmers by processors in transition countries in the past. The strength of the specific monopolistic relations with the buyer, in the context of geographical asset specificity, declines with the increase in the scale of production (it is efficient for a dairy to collect milk only if the truck travels with a full load,

\footnotetext{
3 Temporal specificity was added to Williamsons' concept later by Malone, Yates and Benjamin (1987).
} 
so even a greater distance may be accepted by the other processors) or when there are farms in the neighbourhood which also deliver milk for processing. ${ }^{4}$ For this particular asset specificity, in order to decrease the risk of hold-up, farmers often engage in forms of horizontal quasi-integration (i.e. producer groups, milk collection points, common delivery groups) or deepen integration vertically in the form of the membership of cooperatives or closer contractual arrangements. However, it does not eliminate the hold-up potential range (still quasi-rents might be generated by the processors when breaching the contract), nevertheless it may significantly decrease the probability of its occurrence (Klein 1996).

Physical-asset specificity in agricultural production should, in the light of TCT, be understood differently from only special production-dedicated assets (like milking parlours or cooling tanks on dairy farms, or storage bins for grain). Since, asset specificity is understood in TCT as a transaction-specific investment, with limited value apart from this transaction (Williamson 1998), special dedicated production machinery is not necessarily of this nature and can be used in transactions with the other buyers (other dairies, other grain processors etc.). Thus examples of asset specificity often mentioned in the literature (Gerdoci et al. 2017; Gow and Swinnen 1998; Olilla and Nilsson 1997; Zwanenberg 2001) are equated to the special production equipment. This is not precise, and would only be correct if farmers have no other alternative buyer (which is the rear situation in reality). What could be given here as an example of a transaction-specific asset is a special labelling or packing machine that meets a particular purchaser's requirements, a special storage facility for feed from a particular supplier which must be preserved in special conditions, an installation for heat recovery from cooling milk recommended by a processor who requires higher environmental standards, or enlarging the size of cow stands in a barn to meet the upgraded animal welfare requirements of a particular dairy. All the above examples have value in the transaction only with a certain buyer/ supplier, and are of limited use outside of it.

Using human-asset specificity in order to generate extra quasi-rents in agricultural transactions is an increasingly common practice. Especially in developed countries, agriculture suffers from a lack of qualified labour that can be employed in production. Alongside the land availability, labour is mentioned as the most limiting resource in agricultural production (Kuipers et al. 2017). Together with the development of food quality schemes, often based on unique recipes or practices in production and sales, highly skilled and specifically qualified employees are required. In many situations farmers have to agree for higher salaries or provide extra facilities like

4 This issue is discussed in other authors' papers i.e. Fałkowski, Malak-Rawlikowska and Milczarek-Andrzejewska 2013; Milczarek-Andrzejewska et al. 2008a. 
housing, meals, transport etc. to specifically qualified and experienced employees. Otherwise, they would have to abandon a particular field of production, as happens in many cases.

Taking Williamsons' (1998) understanding of the dedicated assets into consideration, described as an increase in the production scale/powers/facilities dedicated to a particular buyer, this type of specificity is also present in agricultural production and may cause hold-ups. As an example here we can refer to contract farming in pig production, which at the same time is an example of a close and complex vertical interrelationship between seller and buyer. In contract farming, the buyer (in the example, the pork processor) contracts the farmer for a specific amount of production according to strict rules, often using the material provided by the buyer (i.e. piglets, feed). In doing so, the buyer encourages the farmer to upgrade the scale of production and creates a special, upgraded demand. If the contract was broken the products would be difficult to sell on the open market (because it is a large quantity that is ready at a certain moment, and even few days' delay in selling could incur huge losses). For demand reasons, its value in the second best sales option is therefore very low. This is one reason why close vertical integration in such transactions is very common. In line with Williamson (1998) and Perry (2008), vertical integration reduces the likelihood of hold-up problems (the buyer has invested in transaction assets - i.e. piglets, feed - and additionally would lose their reputation in case of unfair behaviour; the farmer has invested in large-scale facilities and knowledge, which on an open market are worth less than in this transaction). However, according to Klein (1996) such a strong relationship, and high specificity of assets would result in big losses for the farmer in the case of opportunistic behaviour by the buyer.

As noted by Hobbs and Young (2001), transaction costs resulting from the specificity of assets in the agri-food sector may thus cause a retreat from market transactions in favour of closer vertical cooperation between transactors. It therefore also affects the structure of the market.

\subsection{Hold-ups and the degree of vertical integration}

The above considerations indicate the need to present the relationship between the specificity of assets, the hold-up problem and the degree of vertical integration. Since processes and conditions of vertical integrations create an almost endless research field, the paper refers only to the views of selected authors regarding potential of vertical relations to mitigate the hold-up risk and some notable examples of vertical relationship studies in the agricultural sector, emphasising imbalances in bargaining-power distribution in the agri-food chain. 
As Coase (1937) argued, the key to understanding vertical relations is not the vertical production relationships, but vertical exchange relationships. Vertical integration is only one method of executing a bilateral exchange. According to Williamson (1998) along with the increase in the specificity of assets dedicated to the transactions necessary to exchange a good or service (thus increasing the possible hold-up range), the need for closer integration links between the buyer and the seller rises. In the case of low specificity of assets, a better form of supply becomes a purchase on the market, due to the lower exchange costs than in the case of internal organisation and control of production costs. Where the specificity of assets is high, the cost of supply on the free market grows. There is also a high risk of falling into a hold-up trap. Williamson therefore claims that a more beneficial solution is the full integration of these processes within the company (Hardt 2008). As an intermediate form of integration between the full vertical integration and closed contracts, ${ }^{5}$ Porter (1998, p. 312) analysed different forms of quasi-integration as means of obtaining "many of the benefits of (full) vertical integration while avoiding many of the costs". He argued that quasi-integration allows the firm to adequately coordinate flows of intermediate inputs, creates common interests of buyer and seller, which may contribute to a reduction of unit costs and the risk of interruptions in supply and demand. Moreover, since it results from the goodwill to share information and from frequent informal contacts, it also reduces the risk of opportunistic behaviour by transaction parties and the potential occurrence of the hold-up problem. One may therefore conclude that along with the growing asset specificity and the associated possible hold-up range, closer vertical relationships are recommended to reduce such risks.

The restructuring of the supply chain has been one of the most remarkable processes observed in the world's agri-food sector in recent years. A broad literature has contributed to improving our understanding of vertical relations throughout the food chain (e.g. Chorób 2017; Dries et al. 2009; Francesconi, Heerink and D’Haese 2010; Jarzębowski 2013; Parzonko 2013; Pietrzak 2006 and 2019; Shuqin, Bluemling and Mol 2015; Strzębicki 2014; Swinnen 2007; Trebbin 2014; Ward 2010). Due to certain specific features (changes in political and economic regimes, market development, food quality and safety standards) this process has been particularly deep in transition countries (Csaki and Forgacs 2007; Dries et al. 2011; Fałkowski 2015; Fałkowski, Malak-Rawlikowska and Milczarek-Andrzejewska 2013; Gow and Swinnen 2001 and 2002; Wilkin et al. 2007). Research both on

5 The potential of contractual vertical integration for reducing hold-up problems is another widely debated strand of literature, i.e. Ellingsen and Johannesson (2004), Hoppe and Smitz (2011), Lyon and Rasmusen (2004), Nöldeke and Schmidt (1995, 1998), Rogerson (1992), Wickelgren (2006) and many others. 
post-socialist and developed countries has shown that the downstream segments have exerted considerable pressure on their suppliers. Thus the biggest challenge for agricultural producers was the need to incur significant investment costs to meet the requirements of their purchasers. However, some studies have proved that changes in the organisation of food chains have had a positive effect on the situation of farms (Fałkowski 2012a and 2012b; Fałkowski, Malak-Rawlikowska and Milczarek-Andrzejewska 2013; Milczarek-Andrzejewska, Malak-Rawlikowska, Fałkowski and Wilkin 2008a and 2008b). In many transition countries, retailers and processors provided support programmes not only to large but also to small suppliers (Briones 2015; Csaki and Forgacs 2007; Dries et al. 2009; MilczarekAndrzejewska 2014).

One of the unique results dealing with the vertical linkages of the farmers in the supply chain, and the role of self-reported bargaining power, was presented in research by Malak-Rawlikowska, Milczarek-Andrzejewska and Fałkowski (Fałkowski, Malak-Rawlikowska and Milczarek-Andrzejewska 2017; Malak-Rawlikowska et al 2018; Malak-Rawlikowska and Milczarek-Andrzejewska 2016; Milczarek-Andrzejewska, Malak-Rawlikowska and Fałkowski 2015). Examining the vertical relations in the dairy chain from the point of view of milk producers, the authors noted that the level of integration differed significantly depending on forward or backward relationships. In the case of forward relations, (e.g. milk purchasers - processing plants), integration had a formal, contractual character, or assumed hybrid forms, where the farmer was a shareholder in the dairy cooperative with the contract for milk supplies and shares at the same time. ${ }^{6}$ These relationships were shaped by long-term arrangements based on formal agreements, and farmers rarely took the opportunity to negotiate the contract terms or change contractors (Milczarek-Andrzejewska, Malak-Rawlikowska and Fałkowski 2015).

Completely different relations were observed in the backward relations to the suppliers of production inputs. It turned out that most of such cases relations and transactions were largely informal, with written contracts being very rare (e.g. purchase of fertilisers, purchase of animal feeds). On the one hand, this creates a freedom of supplier choice, but on the other side, it could generate the risk of changing sales conditions (prices, payments, delivery volumes, frequency etc.) from one purchase to another, and even to either party breaking the informal relationship at any time. However, surprisingly, it was observed that, despite the lack of formal written contract arrangements, relations with input suppliers were longlasting and very stable. The average period of cooperation between the farmer and

6 The phenomenon of the cooperative as a hybrid form of quasi integration was further discussed by Pietrzak $(2006,2019)$. 
feed supplier was over 6.5 years. This striking observation raised a question about the reasons behind such stability in relations.

Despite an extensive literature in the field of vertical relationships in the agrifood chain, only a few studies have directly concerned the problem of transaction costs and imbalanced bargaining-power relationships that might lead to hold-ups in the farming sector (e.g. Dresher 2000; Fernandez-Olmos, Rosell-Martınez and Espitia-Escuer 2009; Gow and Swinnen 2001 and 2002; Hess, Lind and Liang 2013; Holloway et al. 2000). In line with TCT, authors have concluded, among others, that the hold-up problems are related to incomplete contractual arrangements and were especially visible in transitional agriculture because of a combination of contract problems due to the typical characteristics of agriculture and of transition-specific problems (Gow and Swinnen 1998). They also emphasised that the holdup risk increases with growing asset specificity, and closer vertical relationships are recommended to reduce this risk (Gow and Swinnen 2002; Pietrzak 2019). However, institutional arrangements to overcome the hold-up problem, such as supply contracts, cooperatives and vertical integration, were effective as short-term solutions (Gow and Swinnen 1998; Holloway et al 2000). Gow and Swinnen (1998) also emphasised the role of FDI in the process of reducing hold-up problems.

\section{Hold-up range, probability and durability of relations - an example of the farmer-input supplier nexus}

\subsection{Hold-up range as defined by Klein}

As Klein (1996) emphasised, hold-up occurs when unanticipated events put the contractual relationship outside the self-enforcing range. By the self-enforcing range of the contract, ${ }^{7}$ Klein understands both legally binding written terms and the privately enforced unwritten terms of a contract (1996). The self-enforcing range of the contract, where parties enter into contractual relations (knowing that a hold-up may take place but hoping for higher gains from trade outweigh the expected rent-dissipating costs associated with the hold-up risk) is a key to understanding the range and probability of hold-ups. This self-enforcing range of relations is based on conjunction of two factors. One part is a future loss that can be imposed directly on the transactor if the relationship is terminated (for example capital loss of non-salvageable transaction-specific assets/investments equal to the discounted value of quasi-rents from this investment (Klein 1996)).

A contract is understood by Klein (1996), and Perry (2008) in a broad sense and includes all written or unwritten terms agreed by contracting parties in a transaction. They assume a contract relation as bridging the gap between the market and full vertical integration, involving some stage of vertical integration. 
The second part is the potential loss resulting from damage to the transactor's reputation in the market place. If the opportunistic, unfair behaviour of transactor becomes known to the other market partners, the transactor will face the increased costs of future businesses. Most potential market partners will become less trusting and require more favourable contract terms.

Each party compares the potential hold-up gain from breaking the contract understanding, against the capital loss if it happens. Unless the contracts are imperfect (Williamson 1998), or there is no written contract between the transactors and relations are based on privately enforced unwritten terms, the parties tend to respect the mutually agreed relationship intent, rather than ex-post breaching it in order extract the hold-up quasi-rents. The value of transactors' losses when breaching the contract defines Klein's self-enforcing range of the contract, that is, the range within which the market conditions may change. This situation can be illustrated by the example of the dairy farm and cow-feed supplier relations explained in the next section.

\subsection{Hold-up range and durability of relations - an empirical example}

The empirical data used to illustrate the theoretical considerations of this paper come from a questionnaire collected in 2014 with 300 dairy farmers in the Mazovia region of Poland, analysed in the paper by Fałkowski, Malak-Rawlikowska and Milczarek-Andrzejewska 2017; Malak-Rawlikowska and Milczarek-Andrzejewska 2016; Milczarek-Andrzejewska, Malak-Rawlikowska and Fałkowski 2015. It is important, however, to emphasise the motives for choosing the dairy sector for an analysis of vertical relations in the agricultural chain. Dairy production is widely debated in the literature for its inequality in bargaining-power distribution among the chain members, especially between very strong processing companies and farmers, perceived as being in a disadvantageous position vs. downstream chain partners (e.g. Dries et al. 2009; Dries and Swinnen 2004; Fałkowski 2015; Fałkowski, Malak-Rawlikowska and Milczarek-Andrzejewska 2017; Gorton et al. 2014; Wilkin et al. 2007). Moreover, in animal production, relations between farmers and input suppliers assume a specific shape, but have not yet received much empirical attention. In contrast to arable farmers, who purchase inputs (fertilisers, pesticides) mostly occasionally on the spot markets, dairy farmers need to buy feed on constant basis throughout the year. Secondly, in order to increase efficiency and production, farmers increasingly source feeds (especially compound feeds) from the market, instead of producing them themselves, as was common in the past. Very often they also decide for custom feeding. The Polish feed market is therefore characterised by dynamic growth of feed production and strong consolidation 
of feed companies (Malak-Rawlikowska and Milczarek-Andrzejewska 2016; Piwowar 2013). Finally, the last argument is that feed accounts for a considerable share of total costs incurred in dairy production (according to various different studies it ranges from roughly $20 \%$ to $40 \%$ depending on the herd size; Chabuz et al. 2012; Wilczyński 2012). The survey-data include detailed information about farmers' relations with dairy processors and feed suppliers in 2014, with some retrospective questions going back to 2004 .

A Polish dairy-sector study (for more see Malak-Rawlikowska and MilczarekAndrzejewska 2016; Malak-Rawlikowska, Milczarek-Andrzejewska and Fałkowski 2018) showed that the farmers source feed from two main channels: direct purchase from a feed-producing company and purchase from an intermediary in the animal feed sector (e.g. local feed shops). Despite there being two main feed-supply channels, almost $80 \%$ of farmers bought feed produced by only one company, which in most cases was also the farm's sole feed provider. On average, farmers had a long and stable cooperation with feed suppliers (6.5 years). This is further confirmed by the fact that within the previous 10 years the average number of changes of feed suppliers was 1.1 . Further, roughly $45 \%$ of farmers had not changed their feed supplier even once in the previous 10 years. Surprisingly, this long term relationship exists despite the fact that over $90 \%$ of farmers do not have a formal, written contract with their feed provider.

Not surprisingly, farmers mentioned the quality of the feed and the price as the most important aspect of the relationship with feed provider (mentioned by $65 \%$ and $64 \%$ of farmers respectively). However $60 \%$ of farmers did not know if they could buy cheaper feed from a competitive feed provider. These answers stand for farmers acting under incomplete information and it weakens the argument for price as the most important factor in this relationship. Something else seems to play a role here. Namely, when asking about the main barriers to changing the feed supplier, $65 \%$ of farmers mentioned that the cows are accustomed to their supplier's feed. Secondly, $64 \%$ of farmers mentioned the risk of cooperation with a new contractor. Other issues were of less importance. Thus one may assume that this feature significantly affects the transaction costs of changing supplier and may influence the long duration of the relationship.

Let us thus assume a self-reinforcing range of this relationship. The feed supplier would threaten to hold-up the farmer by increasing the price of feed. In reaction to breaching the unwritten contact, the farmer could try to change supplier, imposing on the contractor the loss of discounted value of the future profits from deliveries to the farmer, plus the value of some specific adjustments in technology, if the feed was dedicated to a particular recipe for the farmer. The feed supplier could also lose its reputation, which may result in the additional costs of future contracts. 
However, on the other hand the loss on the farmer's side would be caused by the transaction cost of changing the feed (due to changed feed supplier), which could result in reduced milk yield (or additional veterinary costs), since cows were accustomed to the particular diet (this could also be treated as a transaction-specific physical asset), plus/minus value of additional costs/benefits deriving from the price difference in feeds compared to the second-best supplier option.

Figure 1 attempts to present the self-enforcing range of this relationship, within which the contract will stay in place despite possible changes in contract conditions. Let us assume $\mathrm{P} 1$ as a new, possible, changed price, and $\mathrm{P} 0$ as the agreed contract price, and that a deviation in prices due to the ex-post change in the agreed contract price is shown on the horizontal axis ( $\mathrm{P} 1-\mathrm{P} 0)$. If the feed supplier increases the price the difference is presented on the right-hand side of the horizontal axis. If the farmer renegotiates the contract and receives a discount on the contract price, the difference is presented on the left side of the horizontal axis. Let us also assume that for any deviation in price, there is an adequate gain resulting from a potential hold-up, which is presented on the vertical axis HF - farmer gain (due to discount) and HFS - feed-supplier gain (due to increased price). Assuming, for example, that the farmer buys 100 tonnes of feed, each PLN 100 (zł) deviation in price per tonne creates a potential PLN 10,000 hold-up gain (for the farmer HF or for the feed supplier HFS depending on the direction of the price deviation). The potential hold-up gain as the $\mathrm{P} 1$ changed price deviates from $\mathrm{P} 0$ contract price, is represented by the line $\mathrm{HH}$.

The self-enforcing range (borders) of the farmer-feed-supplier relationship presented is determined by the possible capital losses for each transactor if the contract is breached. For example, let us assume that for the farmer the value of this capital CF is PLN 20,000 (transaction cost of changing the feed supplier i.e. milk yield loss, veterinary costs etc.). Thus the feed supplier can hold-up the farmer and increase the price up to the point that the farmer's cost/feed-supplier gain reaches the CF level of PLN 20,000. The situation is similar in the case of the farmer's potential hold-up of the feed supplier, when the feed price will be reduced due to the farmer's pressure for a discount. If the possible capital loss to feed suppliers CFS amounts to PLN 30,000 (consisting of the lost contract value, potential adjustments in assets, reputation etc.), the feed price can be reduced to this value, and the contract adjustment in price will still be made by the feed supplier.

The entire self-enforcing range of relation includes all price deviations from the contract price between minus PLN 30,000 and plus PLN 20,000. ${ }^{8}$ As Klein

8 Both values of quasi rents are only an example based on a rough estimate, assuming average size of the dairy herd per farm in the sample (27 cows), assumed losses in production efficiency and veterinary 
(1996) discusses, within this range of price deviations, represented in the figure 1 by the SS line between minus PLN 30,000 and plus PLN 20,000, contract terms will be voluntarily adjusted to the market price without breaching it or any side payments being made by the transactors one to another.

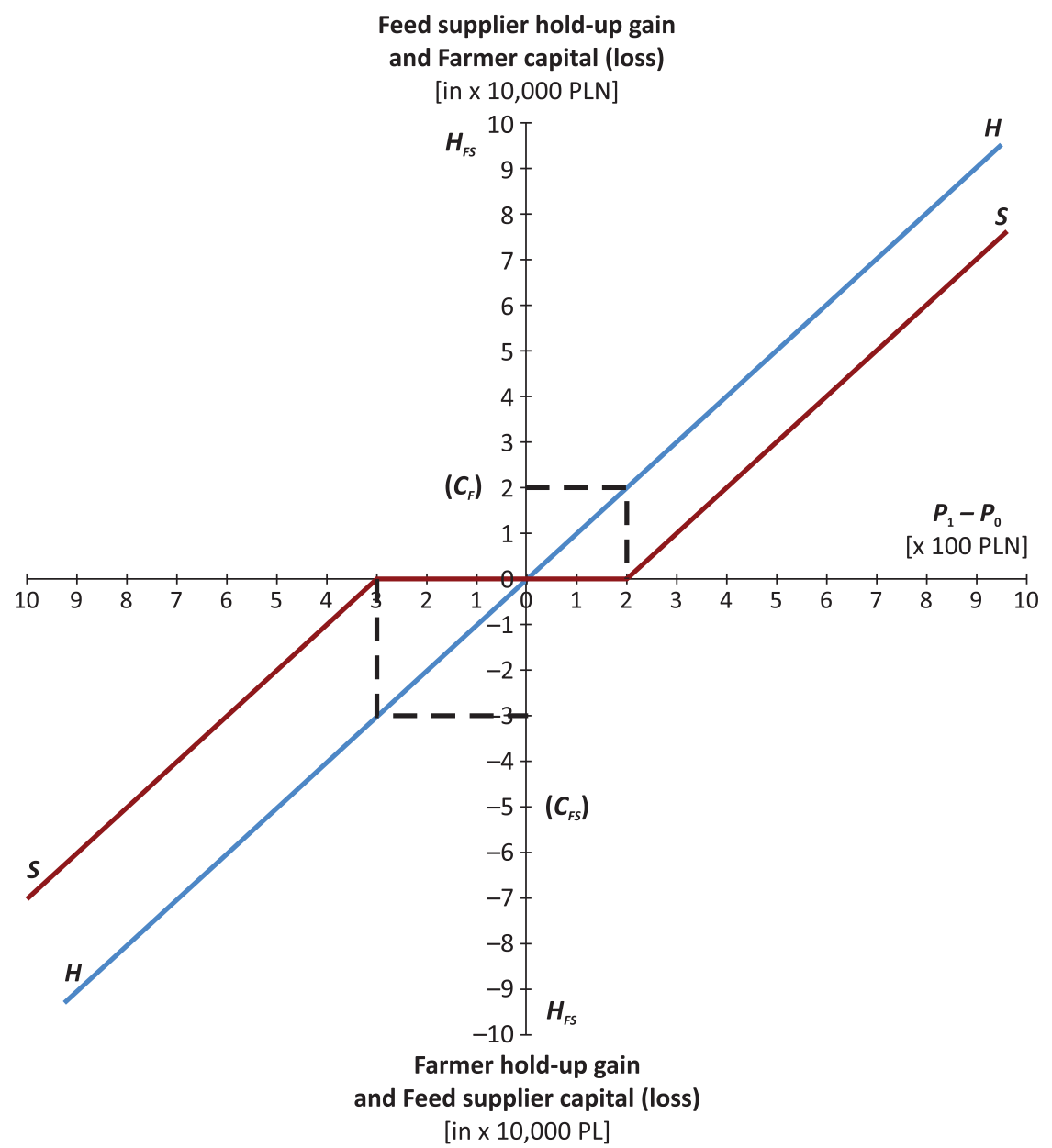

Figure 1. Illustration of the possible hold-up range of the farmer-feed-supplier relationship

Source: Own graph based on Klein's (1996) concept.

costs, and an average value of purchased industrial feeds based on FADN average feed cost purchases per dairy cow in 2016, FADN 2016. Values were discounted and estimated based on the assumed profit margin and time needed for the farmer to switch feed suppliers. Any estimate may differ significantly from reality and was used only to illustrate the hold-up range. 
The above analysis may partly explain why, regardless of changing market conditions (feed prices and discounts), farmers stay in long term relations with feed suppliers. An additional explanation can be added to this picture by analysing why farmers in our case maintain durable relations but without securing them by a written contract.

\subsection{The probability of a hold-up occurrence and contractual arrangements in farmer-feed-supplier relationships}

Williamson (1998) included three basic parameters (contexts) of the transaction which determine its transaction costs: the first and most significant is asset specificity, the second is uncertainty and the third frequency. If there is a high asset specificity in a given transaction, if there is high uncertainty about changes in market conditions, if there is a the risk of opportunistic behaviour by transaction partners, and if the frequency of transactions is high, then a more favourable solution in order to reduce transaction costs and hold-up risk will be full vertical integration. In the opposite situation, the optimum solution would include spotmarket transactions. In a mixed combination of transaction contexts, the optimum solution would include different forms of partial or quasi-integration, depending on the transaction context and a comparison of transaction costs of the market vs. vertical integration. Thus, as stated by Klein (1996), written contractual arrangements, regardless their completeness, reduce the probability of hold-ups. But, conversely, written contracts may increase the hold-up range, when the market conditions push the transaction outside the self-enforcing range. On the other hand, if a contractual understanding is not formalised in a written contract, transactors can opt out more cheaply if subsequent market conditions deviate substantially from expectations (Klein 1996).

As already mentioned in the empirical illustration, farmers loyally buy feed from feed suppliers without written contracts. However, according to Perry (2008), this transaction cannot necessarily can be perceived as a free market or spotmarket purchase. Perry emphasised that in the theory, a "market" exchange is one that requires no negotiation or governance of a continuing relationship. Market transactions are exchanges on spot markets where price, quantity and other dimensions are set by one firm or another (take-it-or-leave-it exchanges). Any other form of relations bridging the gap between the market and full vertical integration may be called contractual arrangements (written or unwritten), involving some stage of vertical integration. So in our case there is an informal contractual arrangement, since $59 \%$ of farmers negotiate prices for feed, $54 \%$ receive discounts and use other forms of quasi-integration such as additional services of feeding advice (33\% use 
them), loans, gifts or premiums. So in our case why do farmers maintain durable relations without securing them by a written contract?

Bearing all this in mind, the contractual situation of farmers sourcing feed from feed providers has the following features. First, the asset specificity in this transaction may be attributed to physical asset specificity and location specificity. The physical asset specificity, as already described, may be attributed to cows being accustomed to a certain type of feed, which was mentioned by farmers as the most significant barrier to changing the feed supplier. Feed change could result in falling milk yields and additional veterinary costs. The location specificity in our case could be expressed by the number of potential alternative feed suppliers. However, as it was found, all farmers had a least one alternative provider, and about $58 \%$ of farmers had even two or more. This was even more (71.2\%) for farmers buying feed from feed producers (versus 52\% for farmers buying from intermediaries). Moreover, only $2 \%$ of farmers regarded finding a substitute feed supplier as difficult or very difficult (Malak-Rawlikowska and Milczarek-Andrzejewska 2016). Overall then, and importantly from our perspective, the picture that emerges from these statistics suggests that the level of asset specificity in transactions between farmers and feed suppliers is rather moderate. Moreover, farmers do not seem to be in the disadvantageous position versus feed suppliers. They can negotiate prices, have alternative contractors and receive discounts on prices of feed (Malak-Rawlikowska, Milczarek-Andrzejewska and Fałkowski 2017). Thus the asymmetry in bargaining power between farmers and feed suppliers is not great and thus the relationship between contractors does not have a strong monopolistic character. This may facilitate informal (unwritten) contractual arrangements of such transactions.

The uncertainty level is a specific trait in every transition. It may be associated with many uncertain factors. Long-term relationships between feed suppliers and farmers may be a solution to reduce risk and uncertainty in this transition (being treated as loyal client by a supplier). What adds to this picture is the fact that unfair behaviour as experienced by farmers in daily transaction reality was very rare. Asked about cases of unfair behaviour by feed suppliers in the past ten years, only $5 \%$ of farmers mentioned such a situation. Moreover, $52 \%$ of farmers emphasised loyalty and trust as one the three most important features of the relationship. The overall picture that comes from these observations suggests that the risk of the unwritten agreement being breached in order to generate quasi-rents from the holdup situation was rather low. This also facilitates long-term and stable relationships in the future.

The third feature of the relationship that might impose the need for a written contract is frequency. If the transitions are infrequent, they are less likely to 
be secured by written agreements. The need to secure transactions by written arrangements increases with their frequency. For feed purchases, the contact between the farmer and the supplier is on constant basis throughout the year. Over $73 \%$ of farmers reported purchasing feed once a month. An important element of the feed purchase, as indicated by farmers, is quality and timely delivery. The frequency of deliveries in this case reduces the risk in this area, because with frequent orders, the amount of feed is not large and a possible quality problem or delay in delivery can be quickly adjusted by the next order. If the level of trust in the relationship is high (as indicated above), the very possibility of breaking the contract determined by the self-enforcing range is sufficient to protect the relationship. So in this case a binding written supply commitment may increase transaction costs, limit the possibility of free change of supplier and reduce farmers' bargaining power versus the feed producer by adding additional interdependency.

\section{Concluding remarks}

Agricultural production is widely discussed in the context of imbalances in bargaining power in the food chain and farmers' difficult position relative to their contractors. Adding agricultural asset specificity, perishability of agricultural produce (which inter alia leads to higher transaction frequency) and the uncertainty level to this situation, there is a potential risk that these bilateral relations between farmers and their contractors my turn into the hold-up situation, where one of the parties attempts to extract quasi-rents, renegotiating the contractual terms.

Notwithstanding the above, the overall picture that emerges from the analysis does not support the assumption that farmers are experiencing a large imbalance in bargaining power versus their input contractors, and are trapped in a specific monopolistic (hold-up) relationship with their suppliers. Very few farmers have been affected by opportunistic behaviour by feed suppliers renegotiating the contractual terms during last ten years, so there is no evidence of Klein's real hold-up relationships in this case.

If there is no written contract between farmers and their suppliers and the relationship is based the privately enforced unwritten terms, the parties tend to respect the mutually agreed relationship, rather than breaching it ex-post in order extract hold-up quasi-rents. Each party compares the potential hold-up gain from breaking the contract understanding, with the subsequent capital loss after its occurrence under certain contractual arrangements. In our case study, the entire self-enforcing range of relations included all price deviations from the contract price between hypothetical hold-up gain for the feed suppliers (equal to capital loss for the farmer) and the hypothetical hold-up gain for the farmer (equal to 
the capital loss for the feed suppliers). Within this range, terms are expected to be voluntarily adjusted to the market price without breaking the relationship. Despite being moderate, the existing self-enforcing range of the relationship may partly explain why, regardless of changing market conditions, farmers remain in stable and long-term relations with feed suppliers.

In this case a binding written supply commitment may increase transaction costs, limit the freedom to change supplier and reduce the farmer's bargaining power versus the feed producer by adding additional inter-dependency. These arguments (features of the transaction) may favour the non-contractual arrangements of such relationships found in the study.

Despite the general theories, which were explained in the paper on the agricultural sector, it should however be emphasised that interpretation of these results may have some objective limitations. First, there is an obvious question as to the extent to which farmers and feed-supplier relationships, being very specific, can be generalised to other farm-input transactions and beyond this particular sample. Second, although the study was illustrated by the empirical results supporting theoretical considerations, due to data availability a deeper comparative analysis of transaction costs of contractual options was not performed. Consequently, even though the results seem rational, they should be perceived as describing the general picture rather than detailed causal dependencies. Nevertheless, these observations suggest some interesting paths for future research.

\section{Bibliography}

Antras P. (2016). Global Production: Firms, Contracts and Trade Structure. Princeton: Princeton University Press.

Briones R.M. (2015). Small farmers in high-value chains: Binding or relaxing constraints to inclusive growth? World Development, 72, 43-52.

Csaki C., Forgacs C. (2007). Restructuring market relations in food and agriculture of Central Eastern Europe: Impacts upon small farmers. In: J.F.M. Swinnen (ed.), Global Supply Chains (pp. 209-227). Standards and the Poor. Oxon: CABI.

Chabuz W., Litwinczuk Z., Teter W. (2012). Pokrycie potrzeb pokarmowych i koszty produkcji mleka w gospodarstwach o różnych systemach żywienia krów. Roczniki Naukowe Polskiego Towarzystwa Zootechnicznego, 8 (2), 27-39.

Chorób R. (2017). Powiązania integracyjne rolnictwa z przemysłem spożywczym na Podkarpaciu. Wiadomości Statystyczne, 6 (673), 73-88.

Coase R.H. (1937). The nature of the firm. Economica, 4 (16), 386-405.

Czyżewski B. (2009). Współczesne teorie renty gruntowej, ich geneza i znaczenie dla Wspólnej Polityki Rolnej w UE. Zeszyty Naukowe SGGW w Warszawie. Polityki Europejskie, Finanse i Marketing, 2 (51), 39-55. 
Czyżewski A., Kułyk P. (2013). Kwestia rolna w teorii wyboru publicznego. Roczniki Naukowe Ekonomii Rolnictwa i Rozwoju Obszarów Wiejskich, 100 (3), 7-17.

Czyżewski A., Kułyk P. (2015). Współczesne ujęcie kwestii rolnej a poglądy Aleksandra Czajanowa i Władysława Grabskiego. Ekonomista, 5, 595-623.

Drescher K. (2000). Assessing aspects of agricultural contracts: An application to German agriculture. Agribusiness, 16 (4), 385-398.

Dries L., Fałkowski J., Malak-Rawlikowska A., Milczarek-Andrzejewska D. (2011). Public policies and private initiatives in transition: Evidence from the Polish dairy sector. Post-Communist Economies, 23 (2), 219-236.

Dries L., Germenij E., Noev N., Swinnen J. (2009). Farmers, vertical coordination, and the restructuring of dairy supply chains in Central and Eastern Europe. World Development, 37 (11), 1742-1758.

Dries L., Gorton M., Urutyan V., White J. (2014). Supply chain relationships, supplier support programmes and stimulating investment: Evidence from the Armenian dairy sector. Supply Chain Management, 19 (1), 98-107.

Dries L., Swinnen J.F.M. (2004). Foreign direct investments, vertical integration and local suppliers: Evidence from the Polish dairy sector. World Development, 32 (9), 1525-1544.

Ellingsen T., Johannesson M. (2004). Is there a hold-up problem? Scandinavian Journal of Economics, 3 (106), 475-494.

Fałkowski J. (2012a). Dairy supply chain modernisation: What about those not keeping pace? European Review of Agricultural Economics, 39 (3), 397-415.

Fałkowski J. (2012b). Vertical coordination from the angle of farmer loyalty and access to capital: Evidence from the Polish dairy sector. Agricultural Economics, 43 (2), 155-164.

Fałkowski J. (2015). Resilience of farmer-processor relationships to adverse shocks: The case of dairy sector in Poland. British Food Journal, 117 (10), 2465-2483.

Fałkowski J., Malak-Rawlikowska A., Milczarek-Andrzejewska D. (2013). Determinants and consequences of participating in a restructured supply chain: The experience of the dairy sector in Poland. Ekonomia, 34, 23-46.

Fałkowski J., Malak-Rawlikowska A., Milczarek-Andrzejewska D. (2017). Farmers' self-reported bargaining power and price heterogeneity: Evidence from the dairy supply chain. British Food Journal, 119 (8), 1672-1686.

Fernandez-Olmos M., Rosell-Martınez J., Espitia-Escuer M.A. (2009). Vertical integration in the wine industry: A Transaction Costs Analysis on the Rioja DOCa. Agribusiness, 25 (2), 231-250.

Francesconi G.N., Heerink N., D’Haese M. (2010). Evolution and challenges of dairy supply chains: Evidence from supermarkets, industries and consumers in Ethiopia. Food Policy, 35, 60-68.

Gerdoci B., Skreli E., Zhllima E., Imami D. (2017). Determinants of long-term business relationships in the dairy value chain in transition countries: The case of Albania. Studies in Agricultural Economics, 119, 139-147.

Gorton M., Angell R., Dries L., Urutyan V., Jackson E., White J. (2014). Power, buyer trustworthiness and supplier performance: Evidence from the Armenian dairy sector. Industrial Marketing Management, 50, 69-77. 
Gorton M., White J. (2007). Transformation and contracting in the supply chains of the former Soviet Union. In: J.F.M. Swinnen (ed.). Global Supply Chains Standards and the Poor: How the Globalisation of Food System and the Standards Affects Rural Development and Poverty (pp. 175-187). Wallingford: CABI.

Gow H.R., Swinnen J.F.M. (1998). Up- and Downstream Restructuring, Foreign Direct Investment, and Hold-Up Problems in Agricultural Transition. European Review of Agricultural Economics, 25 (3), 331-350.

Gow H.R., Swinnen J.F.M. (2001). Private enforcement capital and contract enforcement in transitional economies. American Journal of Agricultural Economics, 83, 686-690.

Gow H.R., Swinnen J.F.M. (2002). Investment, and contract hold-ups in transition: Evidence from Hungary. Paper prepared for presentation at the X EAAE Congress Exploring Diversity in the European Agri -Food System, Zaragoza (Spain), $28^{\text {th }}-31^{\text {st }}$ August 2002, $1-16$.

Hardt Ł. (2008). Rozwój ekonomii kosztów transakcyjnych: Od koncepcji do operacjonalizacji. Warsaw: Fundacja Promocji i Akredytacji Kierunków Ekonomicznych.

Hess S., Lind L.W., Liang S. (2013). Farmers' perceived transaction costs in relation to slaughterhouses of different ownership structure. Agribusiness, 29 (1), 96-111.

Hobbs J.E., Young L.M. (2001). Vertical linkages in agri-food supply chains in Canada and the United States. Report for Research and Analysis Directorate, Strategic Policy Branch, Agriculture and Agri-Food Canada, Ottawa.

Holloway G., Nicholson Ch., Delgado' Ch., Staal S., Ehui S. (2000). Agroindustrialization through institutional innovation transaction costs, cooperatives and milk-market development in the east-African highlands. Agricultural Economics, 23, 279-288.

Hoppe E.I., Smitz Partick W. (2011). Can contracts solve the hold-up problem? Experimental evidence. Games and Economic Behavior, 73, 186-199.

Jarzębowski S. (2013). Integracja łańcucha dostaw jako element kształtowania efektywności sektora przetwórstwa rolno-spożywczego. Treatises and Monographs, 422. Warsaw: Wydawnictwo Szkoły Głównej Gospodarstwa Wiejskiego.

Klein B. (1996). Why hold-ups occur: The self-enforcing range of contractual relationships. Economic Inquiry, 34, 444-463.

Klein B., Crawford R.G., Alchian, A.A. (1978). Vertical integration, appropriable rents, and the competitive contracting process. Journal of Law and Economics, 24, 297-326.

Kuipers A., Malak-Rawlikowska A., Stalgiene A., Klopčič M. (2017). Analysis of stakeholders' expectations for dairy sector development strategies from a Central-Eastern and Western European perspective. German Journal of Agricultural Economics, 66 (4), 265-280.

Kuijpers R., Swinnen J. (2016). Value chains and technology transfer to agriculture in developing and emerging economies. Paper presented at the 2016 Allied Social Sciences Association (ASSA) Annual Meeting, San Francisco, CA, January $3^{\text {rd }}-5^{\text {th }}, 2016,6$.

Lyon T.P., Rasmusen E.B. (2004). Buyer-option contracts restored: Renegotiation, inefficient threats, and the hold-up problem. Journal of Law, Economics, and Organization, $20,148-169$. 
Masten S.E. (2000). Transaction-cost economics and the organization of agricultural transactions. Industrial Organization, 9, 173-195.

Malak-Rawlikowska A., Fałkowski J., Milczarek-Andrzejewska D. (2008). Koncentracja produkcji mleka w Polsce a kanały zbytu. Zagadnienia Ekonomiki Rolnej, 3, 45-59.

Malak-Rawlikowska A., Milczarek-Andrzejewska D. (2016). Farmers relations with input suppliers: Some evidence from the dairy sector in Poland. Wieś i Rolnictwo, 2, 159-172.

Malak-Rawlikowska A., Milczarek-Andrzejewska D., Fałkowski J. (2017). Quantitative assessment of impact of the farmers' self-reported bargaining power on price relations with input suppliers. Contributed paper presented at the XV EAAE Congress Towards Sustainable Agri-food Systems: Balancing Between Markets and Society, August $29^{\text {th }}$ September $1^{\text {st }}, 2017$, Parma, Italy.

Malak-Rawlikowska A., Milczarek-Andrzejewska D., Fałkowski J. (2018). Farmers’ bargaining power and input prices: What can we learn from self-reported assessments? Social Sciences, (in press).

Malone T.W., Yates J., Benjamin R.I. (1987). Electronic markets and electronic hierarchies. Communications of the ACM, 30(6), 484-497.

Milczarek-Andrzejewska D. (2014). Zagadnienie siły w ekonomii: Na przykładzie sektora rolno-spożywczego. Warsaw: Instytut Rozwoju Wsi i Rolnictwa Polskiej Akademii Nauk.

Milczarek-Andrzejewska D., Malak-Rawlikowska A., Fałkowski J. (2015). Pozycja rolników w łańcuchu żywnościowym na przykładzie sektora mleczarskiego w Polsce. Roczniki Naukowe Stowarzyszenia Ekonomistów Rolnictwa i Agrobiznesu, 17(2), 163-168.

Milczarek-Andrzejewska D., Malak-Rawlikowska A., Fałkowski J., Wilkin J. (2008a). Farm-Level Restructuring in Poland. Evidence from Dairy Sector. London: International Institute for Environment and Development.

Milczarek-Andrzejewska D., Malak-Rawlikowska A., Fałkowski J., Wilkin J. (2008b). Regoverning the dairy sector in Poland. Society and Economy, 30(1), 29-77.

Milgrom P., Roberts J. (1992). Economics, Organizations and Management. Englewood Cliffs: Prentice Hall.

Nöldeke G., Schmidt K.M. (1995). Option contracts and renegotiation: A solution to the hold-up problem. Rand Journal of Economics, 26, 163-179.

Nöldeke G., Schmidt K.M. (1998). Sequential investments and options to own. Rand Journal of Economics, 29, 633-653.

OECD (Organisation for Economic Co-operation and Development) (2018), OECD Rural Policy Reviews: Poland 2018. Paris: OECD Publishing.

Ollila P., Nilsson J. (1997). The position of agricultural cooperatives in the changing food industry of Europe. In: Nilsson J., van Dijk G. (eds.), Strategies and Structures in the Agrofood Industries (pp. 131-150). Assen: Van Gorcum.

Parzonko A. (2013). Globalne i lokalne uwarunkowania rozwoju produkcji mleka. Warsaw: Wydawnictwo Szkoły Głównej Gospodarstwa Wiejskiego.

Perry M.K. (2008). Vertical integration: Determinants and effects. In: Schmalensee R., Willig R. (eds.), Handbook of Industrial Organization, 1 (pp. 185-250), Handbooks in Economics, 10. Amsterdam: North Holland. 
Piwowar A. (2013). Rynek pasz przemysłowych w Polsce w latach 2005-2011. Journal of Agribusiness and Rural Development, 3 (29), 111-119.

Pietrzak M. (2006). Efektywność finansowa spótdzielni mleczarskich: Koncepcja oceny. Warsaw: Wydawnictwo Szkoły Głównej Gospodarstwa Wiejskiego.

Pietrzak M. (2019). Spółdzielnie rolników jako fenomen ekonomiczny (in press). Warsaw: CeDeWu.

Porter M.E. (1998). Strategia konkurencji: Metody analizy sektorów i konkurentów. Warsaw: Polskie Wydawnictwo Ekonomiczne.

Rembisz W., Stańko S. (2007). Interwencjonizm państwowy w rolnictwie. In: W. Rembisz, M. Idzik (eds.), Rynek rolny w ujęciu funkcjonalnym (pp. 141-169). Warsaw: Wydawnictwo Wyższej Szkoły Finansów i Zarządzania, Wydawnictwo Instytutu Ekonomiki Rolnictwa i Gospodarki Żywnościowej-Państwowy Instytut Badawczy.

Rogerson W.P. (1992). Contractual solutions to the hold-up problem. Review of Economic Studies, 59, 777-793.

Roman M. (2017). Uwarunkowania i kierunki zmian zasiegu geograficznego rynku mleka surowego w Polsce. Warsaw: Wydawnictwo Szkoły Głównej Gospodarstwa Wiejskiego.

Shuqin J., Bluemling B., Mol A.P.J (2015). Information, trust and pesticide overuse: Interactions between retailers and cotton farmers in China. NJAS - Wageningen Journal of Life Sciences, 72-73, 23-32.

Strzębicki D. (2014). Development of vertical integration in agribusiness with special regard to meat industry. Economic and Regional Studies (Studia Ekonomiczne i Regionalne), 7 (3), 27-40.

Swinnen J.F.M. (2007). The dynamics of vertical coordination in agri-food supply chains in transition countries. In: Swinnen J.F.M. (ed.), Global Supply Chains, Standards and the Poor (pp. 42-58). Oxon: CABI.

Tiessen J.H., Funk T.F. (1993). Farmer bargaining when purchasing machinery and fertilizer: A study in commercial negotiation. Agribusiness, 9, 129-142.

Trebbin A. (2014). Linking small farmers to modern retail through producer organizations: Experiences with producer companies in India. Food Policy, 45, 35-44.

Ward C.E. (2010). Vertical Integration Comparison: Beef, Pork, and Poultry. Oklahoma Cooperative Extension Fact Sheets F-552. Stillwater: Oklahoma Cooperative Extension Service, Oklahoma State University, 1-5.

Wickelgren A.L. (2006). The limitations of buyer-option contracts in solving the holdup problem. Journal of Law, Economics, and Organization, 23, 127-140.

Wilczyński A. (2012). Wielkość stada krów a koszty i dochodowość w produkcji mleka. Roczniki Nauk Rolniczych, Seria G, 99 (1), 69-80.

Williamson O.E. (1989). Transaction cost economics. In: R. Schmalensee, R.D. Willig (eds.), Handbook of Industrial Organization, 1 (pp. 135-182), Handbooks in Economics, 10. Amsterdam: North Holland.

Williamson O.E. (1998). Ekonomiczne instytucje kapitalizmu (trans. J. Kropiwnicki). Warsaw: Wydawnictwo Naukowe PWN.

Williamson, O.E. (2004). Transaction cost economics and agriculture: An excursion. In: G. Van Huylenbroeck, V. Werbeke, L. Lauwers (eds.), Role of Institutions in Rural Policies and Agricultural Markets (pp. 19-37). Bingley: Emerald Group Publishing Ltd. 
Wilkin J. (2009). Ekonomia polityczna reform Wspólnej Polityki Rolnej. Gospodarka Narodowa, 1-2, 1-25.

Wilkin J., Milczarek D., Malak-Rawlikowska A., Fałkowski J. (2007). The Dairy Sector in Poland. London: International Institute for Environment and Development (IIED). http://pubs.iied.org/pdfs/G03290.pdf

Vorley B., Fearne A., Ray D. (eds.) (2007). Regoverning Markets: A Place for Small-Scale Producers in Modern Agrifood Chains. Aldershot: Gover Publishing.

Zwanenberg A. (2001). Will Global Dairy Company be a true co-operative?, Food \& Agribusiness Research, Rabobank International, 1-47.

\section{Czy rolnicy są uwięzieni w relacjach typu hold-up? Przypadek producentów mleka i dostawców pasz}

Streszczenie: Produkcja rolna jest zagadnieniem szeroko dyskutowanym w kontekście braku równowagi siły przetargowej pomiędzy poszczególnymi ogniwami w łańcuchu żywnościowym oraz trudnej pozycji rolników w stosunku do ich kontrahentów. W artykule podjęto próbę wyjaśnienia, w świetle Teorii Kosztów Transakcyjnych (TCT), natury i przyczyn nierównowagi siły przetargowej, która może prowadzić do powstania relacji typu hold-up (zamknięcia) w sektorze rolnym. Aby zawęzić rozległy obszar analizy, dyskusję teoretyczną zilustrowano empirycznym przykładem wstecznych relacji pionowych pomiędzy rolnikami a dostawcami środków produkcji (pasz). W artykule poszukiwano uwarunkowań długotrwałych i stabilnych relacji między rolnikami a dostawcami pasz oraz tego, czy można je częściowo wyjaśnić brakiem równowagi w sile przetargowej, powodującym uwięzienie (zamknięcie) rolników w specyficznych monopolistycznych relacjach z ich kontrahentami. Ogólnie rzecz biorąc, wyniki analizy nie potwierdzają przypuszczenia, że rolnicy odczuwają dużą nierównowagę w zakresie siły przetargowej w stosunku do swoich dostawców i są zamknięci w specyficznej monopolistycznej relacji typu hold-up. Pomimo braku pisemnej umowy między rolnikami a ich dostawcami, ich relacje oparte są na niepisanych, wzajemnie egzekwowanych warunkach. Strony z reguły respektują uzgodnione zasady i nie naruszają ich ex-post, aby korzystać z quasi-rent z tytułu efektu zamknięcia. W analizowanym przypadku pisemne umowy dotyczące dostaw mogłyby zwiększyć koszty transakcyjne, ograniczyć swobodę zmiany dostawcy i zmniejszyć siłę przetargową rolnika w stosunku do producenta pasz poprzez dodanie dodatkowej współzależności.

Słowa kluczowe: nierównowaga siły przetargowej, problem zamknięcia hold-up, integracja pionowa, gospodarstwa mleczne, dostawcy pasz, Teoria Kosztów Transakcyjnych. 